\title{
Correction to: Aedes larval bionomics and implications for dengue control in the paradigmatic Jafna peninsula, northern Sri Lanka
}

Sinnathamby N. Surendran ${ }^{1 *} \mathbb{0}$, Tibutius T. P. Jayadas ${ }^{1}$, Vaikunthavasan Thiruchenthooran ${ }^{1}$, Selvarajah Raveendran², Annathurai Tharsan", Sharanga Santhirasegaram', Kokila Sivabalakrishnan', Suthakar Karunakaran², Bharathy Ponnaiah², Laksiri Gomes³, Gathsaurie N. Malavige ${ }^{3}$ and Ranjan Ramasamy ${ }^{1 *}$ (1)

\section{Correction to: Parasites Vectors (2021) 14:162 https://doi.org/10.1186/s13071-021-04640- 6}

Following publication of the original article [1], it was noted that Additional file 1: Table S1 had been provided with the wrong caption. The correct caption of this file is as follows: Additional file S1: Details of premises selected for field surveys.

The original article has now been updated with the correct caption.

\section{Reference}

1. Surendran SN, Jayadas TTP, Thiruchenthooran V, Raveendran S, Tharsan A, Santhirasegaram S, Sivabalakrishnan K, Karunakaran S, Ponnaiah B, Gomes L, Malavige GN, Ramasamy R. Aedes larval bionomics and implications for dengue control in the paradigmatic Jaffna peninsula, northern Sri Lanka. Parasites Vectors. 2021;14:162. https://doi.org/10.1186/ s13071-021-04640-6.

\section{Publisher's Note}

Springer Nature remains neutral with regard to jurisdictional claims in published maps and institutional affiliations.

\author{
Author details \\ ${ }^{1}$ Department of Zoology, University of Jaffna, Jaffna, Sri Lanka. ${ }^{2}$ Department \\ of Geography, University of Jaffna, Jaffna, Sri Lanka. ${ }^{3}$ Centre for Dengue \\ Research, University of Sri Jayewardenepura, Nugegoda, Sri Lanka.
}

Published online: 21 April 2021
The original article can be found online at https://doi.org/10.1186/s13071021-04640-6.

*Correspondence: noble@univ.jn.ac.lk; rjr200911@yahoo.com

1 Department of Zoology, University of Jaffna, Jaffna, Sri Lanka

Full list of author information is available at the end of the article

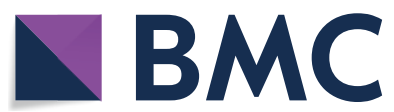

c The Author(s) 2021. This article is licensed under a Creative Commons Attribution 4.0 International License, which permits use, sharing, adaptation, distribution and reproduction in any medium or format, as long as you give appropriate credit to the original author(s) and the source, provide a link to the Creative Commons licence, and indicate if changes were made. The images or other third party material in this article are included in the article's Creative Commons licence, unless indicated otherwise in a credit line to the material. If material is not included in the article's Creative Commons licence and your intended use is not permitted by statutory regulation or exceeds the permitted use, you will need to obtain permission directly from the copyright holder. To view a copy of this licence, visit http://creativeco mmons.org/licenses/by/4.0/. The Creative Commons Public Domain Dedication waiver (http://creativecommons.org/publicdomain/ zero/1.0/) applies to the data made available in this article, unless otherwise stated in a credit line to the data. 